Key Biodiversity Area Special Series

\title{
The identification of sites of biodiversity conservation significance: progress with the application of a global standard
}

\author{
Matthew N. Foster ${ }^{1}$, Thomas M. Brooks ${ }^{2}$, Annabelle Cuttelod ${ }^{3}$, Naamal De Silva ${ }^{4}$, \\ Lincoln D.C. Fishpool ${ }^{5}$, Elizabeth A. Radford ${ }^{6}$ \& Stephen Woodley ${ }^{7}$
}

\author{
${ }^{1}$ National Fish and Wildlife Foundation, 1133 15th Street, NW, Suite 1100, Washington, DC 20005 \\ ${ }^{2}$ NatureServe, 4600 N. Fairfax Dr., 7th Floor, Arlington, VA 22203 USA \\ World Agroforestry Center (ICRAF), University of the Philippines Los Baños, Laguna 4031, Philippines \\ School of Geography and Environmental Studies, University of Tasmania, Hobart TAS 7001, Australia \\ School of Life Science, Sun Yat-sen University, Guangzhou, China \\ ${ }^{3}$ IUCN Species Programme, 219c Huntingdon Road, Cambridge CB3 ODL, UK \\ ${ }^{4}$ Conservation International, 2011 Crystal Drive, Suite 500, Arlington VA 22202, USA \\ ${ }^{5}$ BirdLife International, Wellbrook Court, Girton Road, Cambridge, CB3 ONA, UK. \\ ${ }^{6}$ Plantlife International, 14 Rollestone Street, Salisbury, Wiltshire, SP1 1DX, UK. \\ ${ }^{7}$ Parks Canada Agency, 25 Eddy Street, 4th Floor, Gatineau, Quebec, K1A 0M5, Canada \\ Global Protected Areas Programme, IUCN, 28 rue Mauverney, CH-1196 Gland, Switzerland \\ Email: ${ }^{1}$ matthew.foster@nfwf.org (corresponding author), ${ }^{2}$ tbrooks@NatureServe.org, ${ }^{3}$ annabelle.cuttelod@iucn.org, \\ ${ }^{4}$ n.desilva@conservation.org, ${ }^{5}$ lincoln.fishpool@birdlife.org, ${ }^{6}$ liz.radford@plantlife.org.uk, ${ }^{7}$ stephen.woodley@pc.gc.ca
}

\begin{abstract}
Summary: As a global community, we have a responsibility to ensure the long-term future of our natural heritage. As part of this, it is incumbent upon us to do all that we can to reverse the current trend of biodiversity loss, using all available tools at our disposal. One effective mean is safeguarding of those sites that are highest global priority for the conservation of biodiversity, whether through formal protected areas, community managed reserves, multiple-use areas, or other means. This special issue of the Journal of Threatened Taxa examines the application of the Key Biodiversity Area (KBA) approach to identifying such sites. Given the global mandate expressed through policy instruments such as the Convention on Biological Diversity (CBD), the KBA approach can help countries meet obligations in an efficient and transparent manner. KBA methodology follows the well-established general principles of vulnerability and irreplaceability, and while it aims to be a globally standardized approach, it recognizes the fundamental need for the process to be led at local and national levels. In this series of papers the application of the KBA approach is explored in seven countries or regions: the Caribbean, Indo-Burma, Japan, Macedonia, Mediterranean Algeria, the Philippines and the Upper Guinea region of West Africa. This introductory article synthesizes some of the common main findings and provides a comparison of key summary statistics.
\end{abstract}

Keywords: Endemic, Key Biodiversity Areas, KBA, priority setting, protected area, threatened species.

Date of publication (online): 06 August 2012 Date of publication (print): 06 August 2012 ISSN 0974-7907 (online) | 0974-7893 (print)

\section{Manuscript details:}

Ms \# 03079

Received 21 January 2012

Final revised received 27 March 2012

Finally accepted 26 June 2012

Citation: Foster, M.N., T.M. Brooks, A. Cuttelod, N. de Silva, L.D.C. Fishpool, E.A. Radford \& S Woodley (2012). The identification of sites of biodiversity conservation significance: progress with the application of a global standard. Journa of Threatened Taxa 4(8): 2733-2744.

For Copyright, Author Details, Author Contribution and Acknowledgements see end of this article.

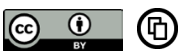

OPEN ACCESS | FREE DOWNLOAD

\section{INTRODUCTION}

Human beings today are confronted with a difficult dilemma regarding global biodiversity conservation. We face a serious crisis as we continue to lose biodiversity at an alarming rate as well as to the environmental benefits it provides. At the same time, societies seem unwilling to make investments in conservation that are commensurate with the enormous scale of the problem. For conservation professionals this means that there

The Key Biodiversity Area series documents the application of the concept and showcases the results from various parts of the world. The series is edited under the auspices of the IUCN World Commission on Protected Areas/Species Survival Commission Joint Task Force on 'Biodiversity and Protected Areas', with the editors supported by BirdLife International, Conservation International, IUCN, National Fish \& Wildlife Foundation, NatureServe, Parks Canada, and Plantlife International.

\section{2. conservation BirdLife INTERNATIONAL

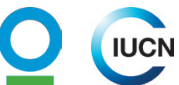


are insufficient resources for biodiversity conservation and the task of conserving our natural heritage appears increasingly daunting. While the papers presented in this special issue of the Journal of Threatened Taxa do not pretend to have the solution for how to solve the biological crisis, or increase societal concern (as expressed by investment), they do provide examples of how sound, data-driven, transparent processes can be used to draw attention to those areas on ground (or water) that are most significant targets for safeguarding biodiversity. Several ways of identifying sites of biodiversity conservation importance have been developed and applied over the past few decades. This special issue focuses on the overarching concept of areas of global biodiversity conservation significance or "Key Biodiversity Areas" (KBAs) and, in particular, on issues associated with the application of the criteria used to identify them in seven countries or regions around the world. Fundamental to the $\mathrm{KBA}$ process is the generation of maximum support for conserving the sites identified, and the use of the best possible information. This is achieved by making the process of identifying KBAs as one that is led by local organizations, but which applies and maintains a globally standardized methodology. The Key Biodiversity Area approach is an effective tool for identifying a priority set of globally significant sites for conservation. Once identified, there is often a need to prioritize where scarce resources should be first directed in order to target the most urgent conservation action.

While KBAs are identified based specifically on biodiversity values, it is recognized that this biodiversity does not exist in isolation and that people often can and should play an important role in the maintenance and management of these areas. For this reason, the issue of manageability is brought directly into decisions regarding the delineation of KBAs. Ultimately, it is hoped that KBAs have the potential to be managed for conservation as single coherent units (e.g. single local government, community group, basin catchment, landowner, etc.). The process explicitly acknowledges that there are several ways in which a KBA can be conserved, either as a formal protected area (e.g. IUCN Class I-VI protected areas; Dudley(2008)) or through other effective means such as community-conserved area, community reserve, indigenous reserve, conservation easement, catchment management, etc. Additionally, it is important to note that while social and cultural aspects of the landscape do not play a role in the identification of KBAs (aside from aspects of boundary delineation), they are significant when planning conservation action.

The development of KBA methodology began with the identification of important sites for birds. This is attributable, at least in part, to the large amounts of data that are available for birds, as a result of their popularity for study by both experts and amateurs. For nearly three decades, the BirdLife International Partnership has been working to identify Important Bird Areas (IBAs) around the world (Fishpool et al. in prep.). IBAs have been identified by local conservation organizations using the same global methodology in all countries, making the resulting priorities comparable. This concept of identifying important areas for a taxonomic group began to be used by other organizations for other groups, such as Important Plant Areas (led by Plantlife International; Anderson (2002), Plantlife (2004)), Important Freshwater Biodiversity Areas (led through the IUCN Freshwater Programme; Darwall \& Vié (2005)) and Prime Butterfly Areas (as identified in Europe by Butterfly Conservation Europe; van Swaay \& Warren (2003)). In order to bring all of these processes and knowledge under a single umbrella methodology and process, an expert workshop was held in 2004 in Washington, DC, USA to develop draft cross-taxon criteria for identifying KBAs. These criteria were laid out in a paper by Eken et al. (2004) and expanded upon by Langhammer et al. (2007), and then were refined for the marine realm by Edgar et al. (2008) and for the freshwater biome by Holland et al. (2012).

\section{KEY BIODIVERSITY AREA CRITERIA}

The two core underlying principles for identification of Key Biodiversity Areas are vulnerability and irreplaceability, both of which are common elements in conservation planning (Margules \& Pressey 2000). While vulnerability is a measure of the scarcity of options in time for conserving biodiversity (often described in terms of the threat level of a given species or ecosystem), irreplaceability is a measure of the spatial options that exist for conserving biodiversity associated with a particular site (e.g. is it the only 
site where the species occurs, or is that species found at 20 other sites?). The greatest significance for immediate conservation action are at those sites where both vulnerability and irreplaceability are high, and conversely, lower at sites which hold less threatened and more widely distributed species and ecosystems. Within the two higher-level criteria of vulnerability and irreplaceability, multiple sub-criteria have been developed (see Table 1).

While very similar, there are differences between the KBA criteria shown in Table 1 and those from which they were derived, for birds, through the Important Bird Area process, and for plants, by the Important Plant Area program-see Appendix 1. A process is ongoing through an IUCN task force (the Species Survival Commission / World Commission on Protected Areas Joint Task Force on Biodiversity and Protected Areas) to explore the applicability of these criteria to other taxa and biomes, and, where appropriate, refine further and standardize these, and other, criteria for identifying sites of biodiversity conservation significance.

The IUCN Red List of Threatened Species serves as the primary basis for incorporating vulnerability into KBA assessments. Nearly 60,000 species have now been assessed by IUCN using standardized criteria, and the associated information is available at www. iucnredlist.org. Sites that hold significant populations of one or more Critically Endangered, Endangered or Vulnerable species may be selected as KBAs. For example, Hellshire Hills in Jamaica qualifies as a KBA because of the presence of three threatened species: one mammal and two birds (Anadón-Irizarry et al. 2012).
One of the irreplaceability sub-criteria concerns restricted-range species. Here, a site may qualify if it holds $\geq 5 \%$ of the population of one or more species of restricted range, currently defined as $50,000 \mathrm{~km}^{2}$, which has proved suitable for terrestrial vertebrates. For plants a restricted-range threshold of $5,000 \mathrm{~km}^{2}$ is more appropriate (e.g Yahi et al. 2012). An example of such a site is Djurdjura in Mediterranean Algeria, which holds significant proportions of 27 such restricted-range plant species. In cases where there are no detailed population data available for species, it is often possible to use surrogates, such as range size, especially when it is simply common sense that a site holds at least $5 \%$ of the population (e.g. when half of the entire range of a species is limited to a single site, or when a fish is known from only one lake).

The second irreplaceability sub-criterion deals with congregations of a species. Here, a species may trigger the sub-criterion if it is known to congregate in numbers exceeding $1 \%$ of the global population at the site. Again, it is often necessary to use surrogates or estimates, given the general lack of detailed data on species populations. Buguey Wetlands, in Luzon, Philippines, holds more than threshold numbers of five congregatory bird species and thus qualifies as a KBA (Ambal et al. 2012). While this criterion has so far been largely applied for birds, it will become more widely used as KBAs are identified for bat roost caves, spawning congregations of fish etc.

The third sub-criterion addresses bioregionally restricted assemblages. To qualify as a KBA under this sub-criterion, a site must hold a significant component of the species restricted to a particular bioregion. The threshold for this criterion has still to be developed

Table 1. Criteria for triggering Key Biodiversity Areas (adapted from Edgar et al. 2008)

\begin{tabular}{|l|l|l|l|}
\hline Criterion & Description & Sub-criterion & Threshold \\
\hline Vulnerability & $\begin{array}{l}\text { Regular occurrence of a globally } \\
\text { threatened species (according to } \\
\text { the IUCN Red List) at the site }\end{array}$ & & $\begin{array}{l}\text { Regular presence of a single individual for Critically } \\
\text { Endangered (CR) and Endangered (EN) species; } \\
\text { Regular presence of } 30 \text { individuals or } 10 \text { pairs for } \\
\text { Vulnerable species (VU) }\end{array}$ \\
\hline \multirow{5}{*}{ Irreplaceability } & $\begin{array}{l}\text { Site holds X\% of a species' global } \\
\text { population at any stage of the } \\
\text { species lifecycle }\end{array}$ & $\begin{array}{l}\text { Restricted-range species } \\
(\text { Species with a global range less } \\
\left.\text { than } 50,000 \mathrm{~km}^{2}\right)\end{array}$ & $5 \%$ of global population at site \\
\cline { 3 - 4 } & $\begin{array}{l}\text { Species with large but clumped } \\
\text { distributions }\end{array}$ & $5 \%$ of global population at site \\
\cline { 2 - 4 } & \begin{tabular}{l} 
Globally significant congregations \\
\cline { 2 - 4 }
\end{tabular} & $\begin{array}{l}\text { Globally significant source } \\
\text { populations }\end{array}$ & $\begin{array}{l}1 \% \text { of global population seasonally present at site } \\
\text { population }\end{array}$ \\
\hline
\end{tabular}


fully, but sites have been identified for birds, using the definition shown in Appendix 1, one specific Indo-Burman example is Tam Dao in Vietnam, which qualified based on the presence of 39 bird species restricted to the Sino-Himalayan Subtropical Forests Bioregion, and nine restricted to the Indochinese Tropical Moist Forest Bioregion (Tordoff 2002).

As mentioned previously, those sites that are extremely vulnerable and completely irreplaceable are potentially in most urgent need of conservation action. The identification and conservation of this set of sites is the aim of the Alliance for Zero Extinction (www.zeroextinction.org). These are KBAs that hold the last remaining population of one or more Critically Endangered or Endangered species and each is therefore both completely irreplaceable and extremely vulnerable - if we lose one of these sites, then we stand to lose at least one species to extinction.

\section{LINKS TO GLOBAL POLICY INSTRUMENTS AND OTHER INITIATIVES}

The identification of sites of global biodiversity conservation significance has a long history of application to policy instruments. The 1971 Ramsar Convention on Wetlands establishes nine standard criteria for the identification of "wetlands of international importance", which have been applied in 160 countries to identify 1,960 sites in total till date (www.ramsar.org). The 1972 World Heritage Convention similarly draws from ten standard criteria, of which four have so far been used to identify 211 natural and natural/cultural World Heritage Sites (whc.unesco.org). All of these criteria can be broadly classified as being based on either irreplaceability or vulnerability.

The 1992 Convention on Biological Diversity (www.cbd.int) added great momentum to the documentation of sites of global biodiversity conservation significance following standard criteria. Its Conference of the Parties Decision VI/9 established a Global Strategy for Plant Conservation, within which Target five requires "Protection of 50 percent of the most important areas for plant diversity assured", with Decision X/17 increasing this to $75 \%$. Under the Thematic Programme on Marine and Coastal Biodiversity, Decision IX/20 established seven "scientific criteria for identifying ecologically or biologically significant marine areas in need of protection"; the Global Ocean Biodiversity Initiative (www.gobi.org) has been established to support such identification. Meanwhile, the Thematic Programme on Mountain Biodiversity aims to "Establish effectively and appropriately managed protected areas in line with the program of work on protected areas to safeguard the highest priority Key Biodiversity Areas in mountain ecosystems" (Decision X/30).

Decision VII/28 of the CBD established the ProgrammeofWorkonProtectedAreas, to "tosupportthe establishment and maintenance, by 2010 for terrestrial and by 2012 for marine areas, of comprehensive, effectively managed, and ecologically representative national and regional systems of protected areas". In 2010, further guidance was provided in Decision X/31 to "Consider standard criteria for the identification of sites of global biodiversity conservation significance, when developing protected area systems drawing on the IUCN Red List of Threatened Species, established criteria in other relevant processes including those of the UNESCO Man and Biosphere Programme, the World Heritage Convention, the Ramsar Convention on Wetlands, threatened ecosystem assessments, gap analysis, Key Biodiversity Areas and Important Bird Areas".

Most important of all, the 2010-2020 Strategic Plan for the Convention on Biological Diversity establishes a shared vision, mission, strategic goals and 20 Aichi Targets (http://www.cbd.int/sp/targets/), of which the eleventh requires the establishment of protected areas covering "by 2020, at least 17 percent of terrestrial and inland water areas, and 10 percent of coastal and marine areas, especially areas of particular importance for biodiversity". Decision X/20 also calls for the scientific bodies and the Liaison Group of the Biodiversity-related Conventions to enhance cooperation regarding "scientific criteria for the identification of ecologically or biologically significant areas in need of protection".

Numerous other sub-global policy instruments draw on standard criteria for identification of sites of biodiversity conservation significance. For example, the European Union's 1979 Birds Directive and 1992 Habitats Directive require, respectively, the designation of Special Protection Areas and Special Areas of Conservation, which together comprise the Natura 
2000 network (www.natura.org). Many national governments draw upon such criteria in undertaking gap analysis and protected-area system planning, towards meeting their commitments to Ramsar, World Heritage, the Convention on Biological Diversity, and other instruments.

Of course, the identification of Key Biodiversity Areas as sites of global biodiversity conservation significance has great importance for many other sectors of society, in addition to its policy applications. In the private sector, the International Finance Corporation's Performance Standard six draws for its safeguard policies on the fact that "Critical habitats are areas with high biodiversity value, including (i) habitat of significant importance to Critically Endangered and/or Endangered species; (ii) habitat of significant importance to endemic and/or restrictedrange species; (iii) habitat supporting globally significant concentrations of migratory species and/ or congregatory species; (iv) highly threatened and/or unique ecosystems; and/or (v) areas associated with key evolutionary processes" (IFC 2012). Similar safeguard policies are in place in other international financial institutions, while the High Conservation Value Resource Network (www.hcvnetwork.org) similarly uses six criteria as safeguards within the certification of high conservation forests and other habitats and ecosystems.

The identification of Key Biodiversity Areas has enormous significance to local and indigenous communities. While difficult to document comprehensively, cases abound whereby local "site support groups" have emerged to implement conservation subsequent to global recognition of such significance. These harness such recognition to generate conservation-related employment and income, stabilization of land tenure, maintenance of ecosystem services, resilience and ecosystem-based adaptation to climate change, educational opportunities, and community pride in local nature. Ultimately, the longterm persistence of the biodiversity for which Key Biodiversity Areas are important will depend as a first line of defense on the people living in and around such sites.

\section{PROGRESS IN IDENTIFICATION OF KEY BIODIVERSITY AREAS}

Important Bird Areas (IBAs), as the avian subset of KBAs, have been identified in nearly all countries, with only a few remaining where inventories have yet to be completed. While the IBA program has been underway for nearly thirty years, the identification of sites of significance for other taxonomic groups is also advancing rapidly. Important Plant Areas (IPAs) inventories have been completed for 36 countries and are partially complete or in progress in further 30 . Much of the focus of the IPA program till date has been in Europe, the Mediterranean parts of North Africa and the Middle East and parts of Asia. The expansion of KBA processes around the world will undoubtedly result in the identification of KBAs triggered by plants, and the network of IPAs will likewise expand. Similarly, the identification of globally important freshwater sites is in progress in more than 90 countries, including continental Africa (Darwall et al. 2011), continental Europe and the Indo-Burma Biodiversity Hotspot. Eighty countries have KBAs identified for multiple taxonomic groups with another 73 partially complete or in progress (see Image 1). Additionally, marine KBA identification is complete or in progress in several marine regions including: Philippines (Ambal et al. 2012), Melanesia, Polynesia-Micronesia, and the Eastern Tropical Pacific.

This special issue examines in detail the results of seven Key Biodiversity Area analyses in the following regions/countries: the Upper Guinea (Kouame et al. 2012) region of West Africa (Côte d'Ivoire, Ghana, Guinea, Liberia, Sierra Leone), the Philippines, the Caribbean Islands, Macedonia (FYR) (Melovski et al. 2012), Algeria (Mediterranean portion), Indo-Burma (Tordoff et al. 2012) and Japan (Natori et al. 2012) (Image 2).

\section{KEY FINDINGS - METHODOLOGICAL ISSUES}

By gathering together the experiences of Key Biodiversity Area identification in seven regions, we can present a picture of the range of challenges faced when applying the criteria. These methodological challenges can be divided into four broad topics:

1. Challenges in using the IUCN Red List as the 


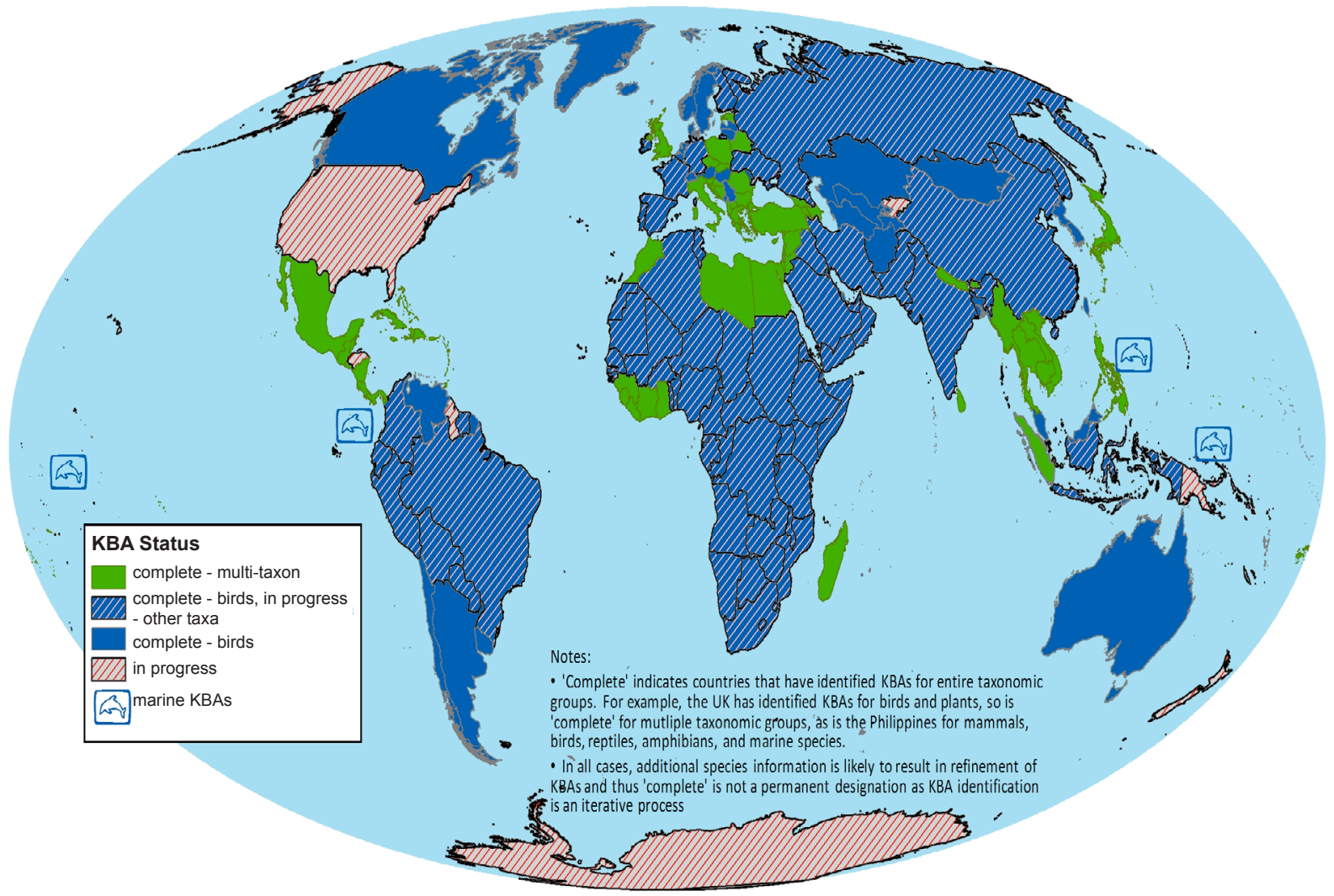

Image 1. Global Progress in Identifying Key Biodiversity Areas

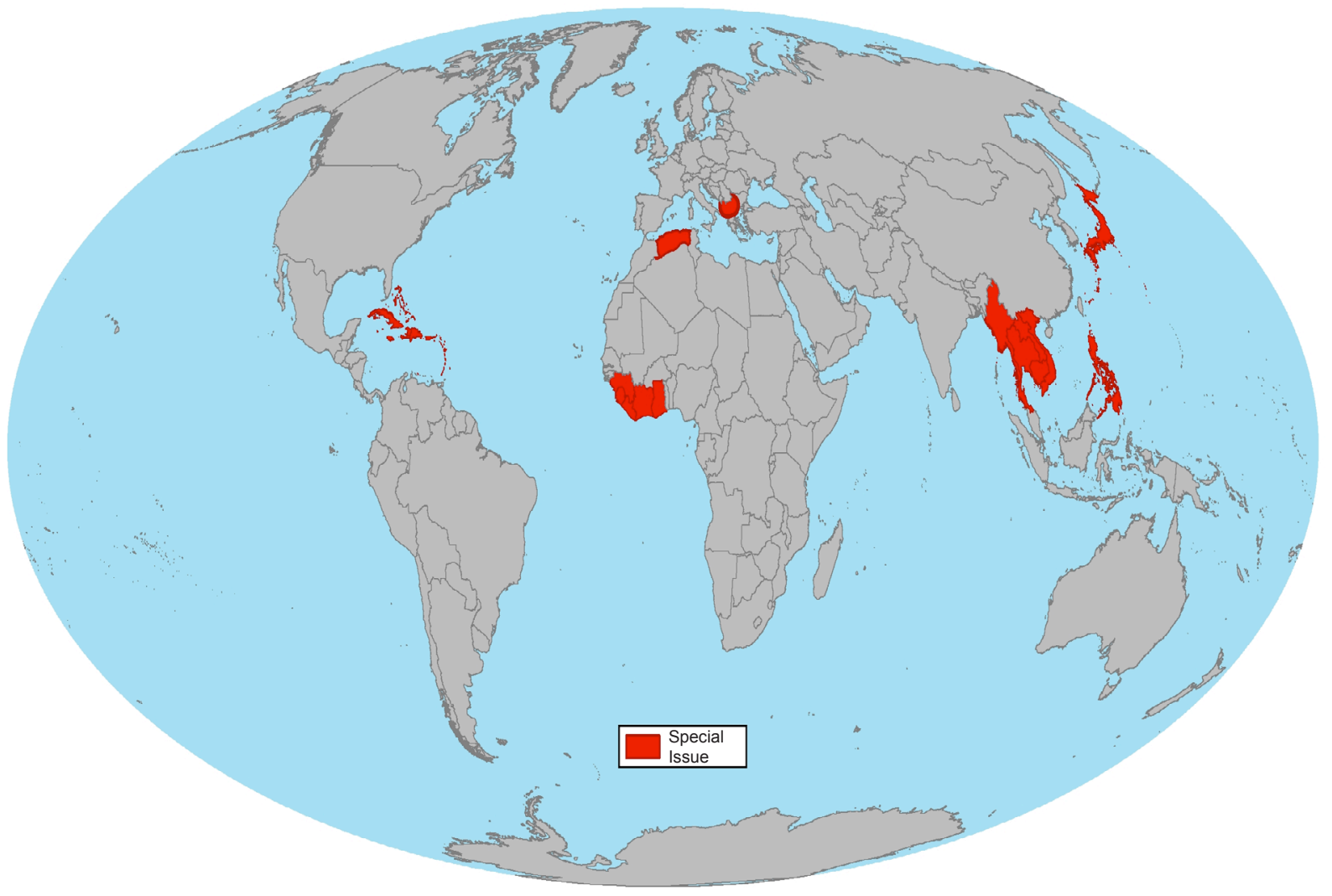

Image 2. Countries and regions with KBA processes described in this special issue 
basis for the vulnerability criterion

2. Discrepancies in application of the criteria in identifying important sites for different taxonomic groups and in different region

3. Application of provisional thresholds for restricted range, and lack of related data for some groups

\section{Delineation challenges}

On the first of these, a consistent challenge is that while more than 60,000 species around the world have now been assessed on the IUCN Red List, there remain significant gaps in coverage among taxonomic groups and regions, and some assessments are out-ofdate. While all regions mentioned the importance of increasing the taxonomic coverage of the IUCN Red List, the taxonomic group felt to be most in need of such effort differed somewhat between regions. For example, while almost all papers suggested there is insufficient assessment of plants, this was not the case for the Caribbean Islands. Also, while recognizing that the IUCN Global Freshwater Species Assessment work is continuing, there currently remains inadequate coverage of such species outside of their recent publication for Africa (Darwall et al. 2011) and what is available on the IUCN website (http://www. iucnredlist.org/initiatives/freshwater).

To compensate, authors often applied other means to capture some of the species that would otherwise have been missed had they relied solely on species on the IUCN Red List. Thus, in Japan, for species other than mammals, birds and amphibians, national endemics that appear on the national red list were used to trigger KBA identification; for these, which have been identified using the IUCN criteria applied at the national scale, the national threat status should prove equivalent to the global Red List status. In the Philippines, the authors ensured that taxonomic groups not well represented under the vulnerability criterion were included through the application of the irreplaceability criteria (specifically, the restrictedrange sub-criterion). Table 2 summarizes the criteria used and taxa covered for each of the countries/ regions.

With regard to discrepancies in criteria application in site identification for different taxonomic groups and regions, two issues were exposed by the Macedonia (FYR) analysis, which combined existing IBA and IPA datasets. Due to small but significant differences between the KBA criteria (Table 1) and the global IBA criteria (Appendix 1), nine Macedonian IBAs did not qualify as KBAs. Thus, for example, species classified as Near Threatened on the IUCN Red List may be used as IBAs triggers but not for KBAs under the vulnerability criterion. However, in four cases the territory of excluded IBAs was retained within the KBA network because it overlapped with a qualifying IPA (e.g. KBA Jakupica). On the other hand, KBA criteria currently incorporate biodiversity data above the species level differently between plants (for which IPAs consider threatened habitats and contextual species richness) and birds (for which IBAs consider biome-restricted assemblages). Thus, five Macedonian IPAs selected using threatened habitat and species richness data are not directly comparable with the Macedonian IBAs, and do not qualify as KBAs in this analysis, although the territory of one of these IPAs does also qualify as an IBA in its own right.

The thresholds for defining restricted-range species was also seen as problematic in several instances. The

Table 2. Taxonomic coverage and criteria application per country/ region

\begin{tabular}{|l|l|l|}
\hline Country/Region & Vulnerability & Irreplaceability \\
\hline Algeria & Plants & Plants \\
\hline Caribbean & Mammals, birds, reptiles, amphibians, plants & Birds \\
\hline Indo-Burma & Mammals, birds, reptiles, amphibians, fishes, plants & Birds \\
\hline Japan & Mammals, birds, reptiles, amphibians, fishes, odonates & Mammals, birds, amphibians \\
\hline Macedonia & Birds, plants & Birds, plants \\
\hline Philippines & $\begin{array}{l}\text { Mammals, birds, reptiles, amphibians, fishes (including reef } \\
\text { fishes), elasmobranchs, molluscs, corals, seagrasses }\end{array}$ & $\begin{array}{l}\text { Mammals, birds, reptiles, amphibians, fishes } \\
\text { (including reef fishes), corals, seagrasses }\end{array}$ \\
\hline Upper Guinea & $\begin{array}{l}\text { Mammals, birds, reptiles, amphibians, fish, crustaceans, } \\
\text { butterflies, plants }\end{array}$ & $\begin{array}{l}\text { Mammals, birds, reptiles, amphibians, fish, } \\
\text { butterflies, plants }\end{array}$ \\
\hline
\end{tabular}


authors of both the Macedonia (FYR) and Algeria papers used a threshold of $5,000 \mathrm{~km}^{2}$ to define restricted range for plant species, since using the proposed $50,000 \mathrm{~km}^{2}$ threshold would have resulted in far too many species qualifying as potential KBA triggers (even so, over 150 plant species in Mediterranean Algeria qualify under the revised threshold). In the Caribbean and Indo-Burma, the KBA processes limited the application of the restricted range sub-criterion to birds, given the paucity of population data for other species.

As for delineation, the biggest concern seems to have been the incorporation of political or management units in demarcation decisions. In Indo-Burma and Macedonia, the authors leaned more toward delineation based on habitat patches and the biological needs of the trigger species, while others, such as Japan, incorporated management layers, such as municipal boundaries, into delineation of KBAs. In several regions, including the Philippines, consultation workshops were viewed as a critical step in achieving the best possible delineation to build consensus around the final set of KBAs. When existing datasets from established analyses are combined, the issue of overlapping sites needs to be addressed. In Macedonia the KBAs that resulted from overlapping IPAs and IBAs were delineated on the basis of the union of their surfaces and, in more complex cases (when two or three KBAs had to be delineated from several overlapping
IPAs and/or IBAs), the boundaries of either IPAs or IBAs were used to delineate KBAs.

A summary of some of the issues encountered in the various regions is given in Table 3 .

\section{KEY FINDINGS - COMPARISON OF RESULTS}

This synthesis of seven papers which have applied an essentially uniform methodology for identifying sites of global biodiversity conservation significance gives us a unique opportunity to review and compare the results between countries and regions. Given the different circumstances, including in size of the region or country, species endemism and richness, threats to natural habitats, intactness of these habitats, relative levels of development etc., it is not surprising there is a considerable range in the number of KBAs identified and in their relative sizes.

Thus, the average size of KBAs ranges from less than $200 \mathrm{~km}^{2}$ (that is, equivalent to squares $14 \mathrm{~km}$ on the side) in the Caribbean to over $800 \mathrm{~km}^{2}$ (equivalent to squares $28 \mathrm{~km}$ on the side) in Upper Guinea (see Table 4). While the small average size of KBAs in the Caribbean is doubtless attributable, in part, to the geography presented by these island systems, there is also considerable fragmentation of natural habitat within the islands, whereas the larger average size in Upper Guinea is surely due in part to the relative

Table 3. Methodological issues in Key Biodiversity Area Identification

Note that this table reflects only those issues reported; blanks do not necessarily mean that an issue or problem of application was not encountered by the authors

\begin{tabular}{|c|c|c|c|c|c|c|c|}
\hline Issue/ Method Application & 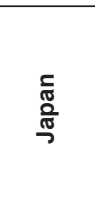 & 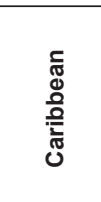 & 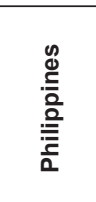 & 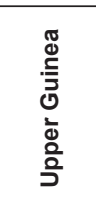 & 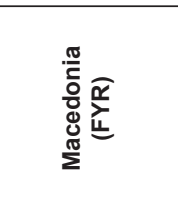 & 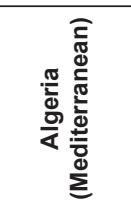 & 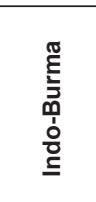 \\
\hline IUCN Red List not up-to-date & $x$ & & & & $x$ & $x$ & \\
\hline IUCN Red List requires greater taxonomic coverage & $x$ & $x$ & $x$ & & $x$ & $x$ & $x$ \\
\hline Threshold used for restricted range & 50,000 & $50,000^{1}$ & 50,000 & 50,000 & $\begin{array}{l}5,000 \text { and } 500 \\
\text { for plants; } \\
50,000 \text { for } \\
\text { birds }\end{array}$ & $\begin{array}{c}5,000 \text { and } \\
1,000 \text { for } \\
\text { plants }\end{array}$ & $50,000^{1}$ \\
\hline Lack of population data for thresholds & $x$ & & $x$ & $x$ & $x$ & $x$ & $x$ \\
\hline Used protected areas as a starting point for delineation & $x$ & & $x$ & $x$ & $x$ & & $x$ \\
\hline Incorporated manageability in delineation decisions & $x$ & & & & & $\mathrm{x}$ & \\
\hline Used biological units to delineate & $\mathrm{x}$ & & & & $x$ & & $x$ \\
\hline
\end{tabular}

${ }^{1}$ Applied only for birds through the Important Bird Area process 
Table 4. Summary KBA Statistics per Country/Region

\begin{tabular}{|c|c|c|c|c|c|c|}
\hline Region/Country & $\begin{array}{l}\text { Total area of } \\
\text { country/region }\end{array}$ & $\begin{array}{l}\text { Combined area } \\
\text { of KBAs }\left(\mathrm{km}^{2}\right)\end{array}$ & $\begin{array}{l}\text { Number of } \\
\text { KBAs }\end{array}$ & $\begin{array}{c}\text { Percentage of } \\
\text { country/region } \\
\text { covered by KBAs }\end{array}$ & $\begin{array}{l}\text { Average size of } \\
\text { KBAs }\left(\mathrm{km}^{2}\right)\end{array}$ & $\begin{array}{c}\text { Number of } \\
\text { threatened } \\
\text { trigger species }\end{array}$ \\
\hline Upper Guinea & 989,963 & 133,107 & 155 & 13 & 859 & 202 \\
\hline Philippines & 51,249 & $70,849.96$ & 178 & $\begin{array}{c}20 \text { (terrestrial), } 2 \\
\text { (marine EEZ) }\end{array}$ & 398 & 396 \\
\hline Macedonia (FYR) & 25,713 & 9,670 & 42 & 38 & 230 & 3 \\
\hline $\begin{array}{l}\text { Algeria (Mediterranean } \\
\text { region) }\end{array}$ & 475,000 & 10,656 & 22 & 3 & 484 & 23 (61?) \\
\hline Caribbean & 228,595 & 50,868 & 284 & 22 & 179 & 409 \\
\hline Indo-Burma & $1,938,745$ & 258,085 & 438 & 12 & 589 & 393 \\
\hline Japan & 374,773 & 68,265 & 228 & 18 & 299 & 133 \\
\hline
\end{tabular}

intactness of the habitat (especially in the west of the region). There also appears to be a gradient from smaller sizes in more developed countries, such as Japan and Macedonia, to larger sizes in less developed ones, which could be due to both greater habitat fragmentation and a finer grain of biodiversity knowledge in developed countries.

As expected, the number and combined area of KBAs in each country/region increases with - and is presumably largely driven by - the number of threatened species in the country/region. However, the size of the country or region itself, the percentage of its territory covered by KBAs, and the average size of KBAs appear to be largely independent of the number of threatened species. Thus, as additional taxonomic groups are assessed by the IUCN Red List, the tallies of threatened species occurring in most countries and regions are likely to increase, and we can anticipate that additional KBAs will need to be identified, yielding a larger combined total area of KBAs but not necessarily larger individual KBAs.

\section{CALL TO ACTION}

There is hope in the fight to stop the current global losses of biodiversity. Worldwide, 187 countries are signatures to the Convention on Biological Diversity and as mentioned previously, the new Strategic Plan for Biodiversity gives these countries a shared vision, mission, strategic goals, and 20 ambitious yet achievable targets to halt the loss of biodiversity. The fact that the global community is giving biodiversity prominence through a uniform approach is encouraging news.
The conservation community must work with the community of nations to conserve the fellow inhabitants of this planet from the excesses of humanity. We need to bring the science, the politics and policy together for urgent action to ensure that biodiversity data, such as KBAs, are incorporated in local, national and regional planning and management. Specifically, we recognize four key recommendations emerging from the KBA process so far, as reflected in the seven contributions to this special issue:

\section{Conserve already-recognized sites}

Sites of global biodiversity conservation significance have already been identified in every country in the world, whether as IBAs, IPAs, AZE sites, or other KBAs. The single greatest contribution which the world's nations can make towards their commitment to Aichi Target 11 is to ensure that:

a) Those sites that are already being conserved by protected areas or other effective mechanisms continue to be effectively managed in ways consistent with the maintenance of the biodiversity for which they are important; and,

b) Those sites not yet being conserved are urgent targets to safeguard through the establishment of new protected areas or other effective mechanisms;

\section{Fully utilize the IUCN Red List in site identification}

The last decade has seen enormous advances in the taxonomic coverage of the IUCN Red List (Rodrigues et al. 2006), making available large quantities of data on the distribution and extinction risk of, for example, amphibians, fishes, odonates, and plants. Where these data have not yet been incorporated into national 
processes for identifying sites of global biodiversity conservation significance, doing so is an urgent priority.

3. Continue to expand the taxonomic coverage of the Red List, to increase the quality and quantity of up-to-date data, as well as their availability, on species, taxonomy and habitats

Despite recent advances in coverage, substantial biases remain. IUCN has mobilized a "Barometer of Life" campaign, targeting more comprehensive Red Listing of plants, fungi, reptiles, and freshwater and marine taxa.

\section{Strengthen the application of global standards in national site identification}

The increasing globalization of our world places increasing demands for standardization of the processes for identifying significant sites, to fulfill the needs of international conventions, the international financial institutions and development banks, and the private sector. As the work of the IUCN WCPA/SSC Joint Task Force delivers more uniform standards for the identification of important sites, we anticipate that national application of these standards will provide ever greater conservation benefit.

Finally, KBAs' identification is an iterative process and we can only encourage people to continue identifying sites of global biodiversity conservation significance in countries, biomes or taxonomic groups that have still not been taken into consideration.

\section{For further information (hyperlinks)}

IUCN WCPA-SSC Joint Task Force - http://www. iucn.org/about/union/commissions/wcpa/wcpa_what/ wcpa_science/biodiversity_and_protected_areas/

BirdLife Important Bird Areas - http://www. birdlife.org/datazone/site

IPA website - http://www.plantlifeipa.org/reports. asp

Prime Butterfly Areas - http://www.bc-europe.org/ category.asp?catid $=10$

Integrated Biodiversity Assessment Tool - https:// www.ibat-alliance.org/ibat-conservation/

Alliance for Zero Extinction - http://www. zeroextinction.org/

\section{REFERENCES}

Anadón-Irizarry, V., D.C. Wege, A. Upgren, R. Young, B. Boom, Y.M. León, Y. Arias, K. Koenig, A.L. Morales, W. Burke, A. Perez-Leroux, C. Levy, S. Koenig, L. Gape \& P. Moore (2012). Sites for priority biodiversity conservation in the Caribbean Islands Biodiversity Hotspot. Journal of Threatened Taxa 4(8): 2806-2844.

Ambal, R.G.R., M.V. Duya, M.A. Cruz, O.G. Coroza, S.G. Vergara, N. de Silva, N. Molinyawe \& B.B. Tabaranza (2012). Key Biodiversity Areas in the Philippines: Priorities for Conservation. Journal of Threatened Taxa 4(8): 27882796.

Anderson, S. (2002). Identifying Important Plant Areas. Plantlife International, London, UK, 52pp.

Darwall, W.R.T. \& J.C. Vié, (2005). Identifying Important Sites For Conservation of Freshwater Biodiversity: Extending The Species-Based Approach. Gland, Switzerland and Cambridge, IUCN, UK, 287-293pp.

Darwall, W.R.T., K.G. Smith, D.J. Allen, R.A. Holland, I.J. Harrison \& E.G.E. Brooks (eds) (2011). The Diversity of Life In African Freshwaters: Under Water, Under Threat. An Analysis Of The Status And Distribution Of Freshwater Species Throughout Mainland Africa. Cambridge, UK and IUCN, Gland, Switzerland, 348pp.

Dudley, N. (Ed.) (2008). Guidelines for Applying Protected Area Management Categories. IUCN, Gland, Switzerland, 86pp.

Edgar G.J., P.F. Langhammer, G. Allen, T.M. Brooks, J. Brodie, W. Crosse, N. Da Silva, L.D.C. Fishpool, M.N. Foster, D.H. Knox, J.E. McCosker, R. McManus, A.J.K. Miller \& R. Mugo (2008). Key Biodiversity Areas as globally significant target sites for marine conservation. Aquatic Conservation: Marine and Freshwater Ecosystems 18: 969-983.

Eken, G., L. Bennun, T.M. Brooks, W. Darwall, L.D.C. Fishpool, M. Foster, D. Knox, P. Langhammer, P. Matiku, E. Radford, P. Salaman, W. Sechrest, M.L. Smith, S. Spector \& A. Tordoff (2004). Key biodiversity areas as site conservation targets. BioScience 54: 1110-1118.

Fishpool, L.D.C., L. Bennun, J. Arinaitwe, I. Burfield, R. Clay, M.I. Evans, M.F. Heath, A.B. Gammell \& R.F. Grimmett (in prep.). Important Bird Areas: BirdLife International's approach to site-based conservation.

Holland, R.A., W.R.T. Darwall \& K.G. Smith (2012). Conservation priorities for freshwater biodiversity: The Key Biodiversity Area approach refined and tested for continental Africa. Biological Conservation 148(1): 167-179.

IFC (2012). Performance Standard 6. Biodiversity Conservation and Sustainable Management of Living Natural Resources. International Finance Corporation, Washington DC, USA. See http://www.ifc.org/ifcext/policyreview.nsf/Content/ PerformanceStandard6.

Kouame, O.M.L., N. Jengre, M. Kobele, D. Knox, D.B. Ahon, J. Gbondo, J. Gamys, W. Egnankou, D. Siaffa, A. Okoni-Williams \& M. Saliou (2012). Key Biodiversity Areas identification in the Upper Guinea forest biodiversity 
Appendix 1. Criteria and Thresholds for Important Bird Areas and Important Plant Areas

Important Bird Area criteria (adapted from http://www.birdlife.org/datazone/info/ibacritglob)

\begin{tabular}{|c|l|l|}
\hline \multicolumn{2}{|c|}{ Criterion } & Definition \\
\hline \multirow{2}{*}{ A1 } & $\begin{array}{l}\text { Species of global conservation } \\
\text { concern }\end{array}$ & Site regularly holds significant numbers of a globally threatened or near-threatened species \\
\hline \multirow{2}{*}{ A2 } & $\begin{array}{l}\text { Assemblage of restricted-range } \\
\text { species }\end{array}$ & $\begin{array}{l}\text { Site is known or thought to hold a significant component of the restricted-range bird species whose } \\
\text { breeding distributions define an Endemic Bird Area (EBA) or Secondary Area (SA). }\end{array}$ \\
\hline \multirow{2}{*}{ A3 } & Biome-restricted assemblages & $\begin{array}{l}\text { The site is known or thought to hold a significant component of the group of bird species whose } \\
\text { distributions are largely or wholly confined to one biome. }\end{array}$ \\
\hline \multirow{2}{*}{ A4 } & Congregations & $\begin{array}{l}\text { (i) The site is known or thought to hold, on a regular basis, 1\% of a biogeographic population of a } \\
\text { congregatory waterbird species. }\end{array}$ \\
\cline { 2 - 3 } & & $\begin{array}{l}\text { (ii) The site is known or thought to hold, on a regular basis, 1\% of the global population of a } \\
\text { congregatory seabird or terrestrial species. }\end{array}$ \\
\cline { 2 - 3 } & & $\begin{array}{l}\text { (iii) The site is known or thought to hold, on a regular basis, 20,000 waterbirds or 10,000 pairs of } \\
\text { seabirds of one or more species. }\end{array}$ \\
\cline { 2 - 3 } & (iv) The site is known or thought to exceed thresholds set for migratory species at bottleneck sites. \\
\hline
\end{tabular}

Important Plant Area criteria (adapted from Anderson 2002)

\begin{tabular}{|c|c|c|}
\hline Criterion & Description & Threshold \\
\hline$A(i)$-threatened species & Site contains globally threatened species & \multirow{4}{*}{$\begin{array}{l}\text { All sites known, though or inferred to contain } 5 \% \text { or more } \\
\text { of the national population can be selected, or the } 51 \\
\text { 'best' sites, whichever is the most appropriate. }\end{array}$} \\
\hline A(ii) - threatened species & Site contains regionally threatened species & \\
\hline$A(i i i)$ - threatened species & $\begin{array}{l}\text { Site contains national endemic species with } \\
\text { demonstrable threat not covered by } A(i) \text { or } A(i i)\end{array}$ & \\
\hline $\begin{array}{l}A(\text { iv) - (threatened } \\
\text { species) }\end{array}$ & $\begin{array}{l}\text { Site contains near endemic/restricted range species with } \\
\text { demonstrable threat not covered by } \mathrm{A}(\mathrm{i}) \text { or } \mathrm{A}(\mathrm{ii})\end{array}$ & \\
\hline B - botanical richness & $\begin{array}{l}\text { Site contains high number of species within a range of } \\
\text { defined habitat or vegetation type }\end{array}$ & $\begin{array}{l}\text { Up to } 10 \% \text { of the national resource (area) of each habitat } \\
\text { or vegetation type, or } 52 \text { best sites; whichever is the } \\
\text { most appropriate. }\end{array}$ \\
\hline $\begin{array}{l}\text { C - threatened habitat or } \\
\text { vegetation type }\end{array}$ & Site contains threatened habitat or vegetation type & $\begin{array}{l}\text { All sites known, thought or inferred to contain } 5 \% \\
\text { or more of the national resource (area) of priority } \\
\text { threatened habitats can be selected, or a total of } 20 \text { - } \\
60 \% \text { of the national resource, whichever is the most } \\
\text { appropriate. }\end{array}$ \\
\hline
\end{tabular}

hotspot. Journal of Threatened Taxa 4(8): 2745-2752.

Langhammer, P.F., M.I. Bakarr, L.A. Bennun, T.M. Brooks, R.P. Clay, W. Darwall, , N. De Silva, G.J. Edgar, G.

Eken, L.D.C.Fishpool, Fonseca, G.A.B. da, M.N. Foster, D.H. Knox, P. Matiku, E.A. Radford, A.S.L. Rodrigues, P. Salaman, W. Sechrest \& A.W. Tordoff (2007). Identification and Gap Analysis of Key Biodiversity Areas: Targets for Comprehensive Protected Area Systems.IUCN, Gland, Switzerland, 134pp.

Margules, C.R. \& R.L. Pressey (2000). Systematic Conservation Planning. Nature 405: 243-253.

Melovski, Lj., M. Velevski, V. Matevski, V. Avukatov \& A. Sarov (2012). Using important plant areas and important bird areas to identify Key Biodiversity Areas in the Republic of Macedonia. Journal of Threatened Taxa 4(8): 2766-2778.

Natori Y., M. Kohri, S. Hayama \& N. De Silva (2012). Key Biodiversity Areas identification in Japan Hotspot. Journal of Threatened Taxa 4(8): 2797-2805.

Plantlife (2004). Identifying and Protecting the World's most important Plant Areas: A Guide to Implementing Target 5 of the Global Strategy for Plant Conservation. Plantlife International, Salisbury, United Kingdom, 8pp.
Rodrigues, A.S.L., J.D. Pilgrim, J.F. Lamoreux, M. Hoffman \& T.M. Brooks (2006). The value of the IUCN Red List for conservation. Trends in Ecology \& Evolution 21: 71-76.

Tordoff, A.W. (ed.) (2002). Directory of Important Bird Areas in Vietnam: Key Sites for Conservation. BirdLife International in Indochina and Institute of Ecology and Biological Resources, Hanoi, 233pp.

Tordoff, A.W., M.C. Baltzer, J.R. Fellowes, J.D. Pilgrim \& P.F. Langhammer (2012). Key Biodiversity Areas in the IndoBurma Hotspot: Process, Progress and Future Directions. Journal of Threatened Taxa 4(8): 2779-2787

van Swaay, C.A.M. \& M.S. Warren (2003). Prime Butterfly Areas in Europe: Priority Sites for Conservation. Wageningen, Netherlands: National Reference Center for Agriculture, Nature and Fisheries: Ministry of Agriculture, Nature Management and Fisheries, 690pp.

Yahi, N., E. Vela, S. Benhouhou, G. De Belair \& R. Gharzouli (2012). Identifying Important Plants Areas (Key Biodiversity Areas for Plants) in northern Algeria. Journal of Threatened Taxa 4(8): 2753-2765. 
Copyright: () Matthew N. Foster, Thomas M. Brooks, Annabelle Cuttelod, Naamal De Silva, Lincoln D.C. Fishpool, Elizabeth A. Radford \& Stephen Woodley 2012. Creative Commons Attribution 3.0 Unported License. JoTT allows unrestricted use of this article in any medium for non-profit purposes, reproduction and distribution by providing adequate credit to the authors and the source of publication.

\section{Author Details:}

Matthew N. Foster is the Monitoring and Biodiversity Officer at the National Fish and Wildlife Foundation, where he provides mapping and analysis skills to institutional strategy development and monitoring implementation. Matt graduated with a Bachelor's degree in Latin American Studies from the University of Illinois in 1995 and earned his Master's at Boston University in Energy and Environmental Analysis (1999). Before joining the National Fish and Wildlife Foundation, Matt worked for ten years with Conservation International focusing on the identification of priorities for biodiversity conservation around the world.

THOMAS M. BROOKs, from Brighton, U.K., holds a B.A. (Hons) in Geography from the University of Cambridge (1993) and a Ph.D. in Ecology and Evolutionary Biology from the University of Tennessee (1998). He is the Vice President for Science and Chief Scientist at NatureServe. He is an ornithologist by training, with field experience in tropical forests of Asia, South America and Africa. His interests lie in threatened species conservation and in biodiversity hotspots. $\mathrm{He}$ has served on the IUCN Red List Committee since 2001, the Steering Committee of its Species Survival Commission since 2004, and as co-chair of its joint taskforce on 'Biodiversity and Protected Areas' since 2009.

AnNABelle Cuttelod is currently a Conservation Planning Programme Officer at IUCN Globa Species Programme, working towards the consolidation of a global standard to identify sites of importance for biodiversity conservation. This is one of the objectives of the IUCN Joint Task Force, between the Species Survival Commission (SSC) and the World Commission on Protected Areas (WCPA)

Annabelle graduated in biology at Lausanne University and earned a Masters degree in Oceanography at Aix-en- Provence University. Her species conservation experience includes serving as Regional Red Lists Coordinator and as Mediterranean Species Coordinator, involvement with the Swiss Cetacean Society, and as a consultant working with the private sector.

NaAmal De Silva is Director, Conservation Priorities and Outreach at Conservation International. She joined $\mathrm{Cl}$ in 2004, initially to work with the Marine Rapid Assessment Program. Her current role includes developing Cl's institutional framework for identifying geographic priorities, providing technical support to field programs on priority-setting, and helping to link science staff in $\mathrm{Cl}$ headquarters with technical staff in the field. Naamal's background includes work on identifying globally significant sites for biodiversity conservation, and she maintains links with IUCN, BirdLife International, and the Alliance for Zero Extinction in pursuing this work. She has a B.A. in Biology and Environmental Studies from Swarthmore College, a Master's in Environmental Management from Yale University, and recently began a doctora program in Education at George Washington University. Her research interests include conservation biology, environmental education and the cultural aspects of conservation; she has carried out fieldwork related to these topics in Sri Lanka, Ghana, Costa Rica, and New Caledonia.

LINCOLN D.C. FishPOoL is Global Important Bird Area Coordinator for BirdLife International, based in Cambridge, UK. His role includes oversight of technical aspects of the IBA programme, including application of the criteria and thresholds by which sites are identified. Lincoln has a Ph.D. from the University of London (1982) on the ecology and biogeography of West African grasshoppers and worked fo 17 years as an entomologist with the British Government's overseas aid programme in several countries in Africa. He joined BirdLife in 1993 where he initially coordinated the IBA programme for Africa.

ELIZABETH A. RADFORD has worked for Plantlife International for 14 years - a non government organisation that works to protect wild plants and their habitats and to build an understanding of the vital role they play in everyone's lives. She is currently International Programme Manager which includes managing the Important Plant Areas (IPAs) programme which aims to conserve the best places in the world for wild plants. Elizabeth has a BSc in Botany (Wales, 1993) and a MSc in the Biodiversity and Taxonomy and of Plants (Edinburgh, 1998).

Stephen Woodley is the Senior Advisor on Biodiversity and Climate Change for the
International Union for the Conservation of Nature. He is on secondment to the IUCN from Parks Canada where he was Chief Ecosystem Scientist. $\mathrm{He}$ is Co-Chair of the Joint Task Force on Biodiversity and Protected Areas, joint between the World Commission on Protected Areas and the Species Survival Commission. This Task Force is looking at developing criteria for areas of global significance to the persistence of biodiversity. Stephen got his $\mathrm{PhD}$ from the University of Waterloo.

\section{Author Contribution:}

MNF was the lead author of the study and paper, as well as map design. TMB, AC, NDS, LDCF, EAR, and SW contributed knowledge and expertise in synthesizing the special issue papers and analyzing results. Each also contributed further in providing text and editing.

\section{Acknowledgements:}

The KBAs process in West Africa was made possible with the support of a number of environmental NGOs, government Institutions and agencies as well as individual experts. In Ghana, they include the Ghana Environmental Protection Agency, Ghana Ministry of Environment Science and Technology, Ghana Forestry Commission, Forestry Research Institute of Ghana, Ghana Wildlife Division, and the Resource Management Support Centre of the Ghana Forestry Commission. Others are the Ghana Wildlife Society, BirdLife InternationalGhana, Friends of the Earth - Ghana, West African Primate Conservation Action - Ghana, Centre for African Wetlands - Ghana, Butterfly Conservation of Ghana, University of Ghana, University for Development Studies - Ghana and University of Cape Coast - Ghana. Beyond Ghana, key institutions include the Conservation Society of Sierra Leone, SOSFORETS of Côte d'Ivoire, Guinee - Ecologie, University of Conakry, University of Cocody - Abidjan, Centre National de Floristique Abidjan, Société de Développement des Forêts - Côte d'Ivoire, Office Ivoirien des Parcs et Réserves - Côte d'Ivoire, Direction des Parcs Nationaux - Côte d'Ivoire, Centre Suisse de Recherches Scientifiques - Côte d'Ivoire, Wild Chimpanzee Foundation - Côte d'lvoire, Centre d'Etude et de Recherche en Environnement (Guinea), Ministry of Environment of Guinea, Centre National de Recherche Halieutique of Boussoura - Guinea, Ministry of Agriculture of Sierra Leone, Forestry and Food Security, Ministry of Fisheries and Marine Resources of Sierra Leone, Bumbuna Hydroelectric Project, Institute of Marine Biology and Oceanography, University of Sierra Leone (Department of Biological Sciences, Fourah Bay College) and Department of Biological Sciences - Njala, Forestry Development Authority of Liberia, Society for Conservation of Nature of Liberia, Fauna and Flora International - Liberia. 